\title{
Comperative study of aboveground biomass and carbon storage between Tembawang and conventional rubber agroforestry in West Kalimantan Indonesia
}

\author{
Rafdinal RAFDINAL ${ }^{1,2}$, Ramadanil PITOPANG ${ }^{3}$, Riza LINDA ${ }^{1}$, Adityo RAYNALDO ${ }^{4}$, Eko SUBRATA ${ }^{5}$
}

Received September 01, 2020; accepted December 08, 2020.

Delo je prispelo 01. septembra 2020, sprejeto 08. decembra 2020.

Comperative study of aboveground biomass and carbon storage between Tembawang and conventional rubber agroforestry in West Kalimantan Indonesia

Abstract: In the era of intensive oil palm and rubber plantations in Kalimantan, some local communities of Dayak's tribe in West Kalimantan preserved the traditional agroforestry system "Tembawang". In the last two decades, rubber has been planted traditionally by local communities since the expansion of rubber industries. This study aimed to compare tree above ground biomass (AGB) distribution and carbon storage in different DBH (diameter at breast height) classes between Tembawang and conventional rubber plantation in West Kalimantan, Indonesia. Vegetation transect analysis was carried out on two types of traditional agroforestry namely Tembawang and conventional rubber. AGB estimation was based on the existing allometric, carbon storage was estimated from the percentage of biomass. Total AGB of Tembawang was higher than conventional rubber plantation and significantly different $(p$ $<0.01$ ). The highest AGB accumulation both Tembawang and conventional rubber was found at above $50 \mathrm{~cm}$ diameter class. The aboveground carbon storage from Tembawang and conventional rubber plantation were 90.26 and $42.01 \mathrm{Mg} \mathrm{C}^{-1}$, respectively. The highest contribution to carbon storage was found at above $50 \mathrm{~cm}$ diameter class, estimated $62.58 \%$ from Tembawang and $49.24 \%$ from conventional rubber. AGB and carbon storage at traditional agroforestry in West Kalimantan were greater than varied different agroforestry system, also the estimated value was closed to tropical secondary forests. Tembawang agroforestry has good potential contribution to carbon storage and conservation of native fruit trees of Kalimantan.

Key words: carbon storage; Dayak's tribe; ethnoecology; plantation; Tembawang
Primerjalna raziskava nadzemne biomase in shranjevanja ogljika med Tembawangom in konvencionalnim pridobivanjem kavčuka $\mathbf{v}$ Zahodnem Kalimantanu, Indonezija

Izvleček: V obdobju intenzivnega gojenja oljne palme in plantaž kavčukovca v Kalimantanu so nekatere lokalne skupnosti plemena Dajakov v Zahodnem Kalimantanu ohranile tradicionalni kmetijsko gozdarski sistem (agroforestry), imenovan “Tembawang”. Kljub povečevanju industrije kavčuka v zadnjih desetletjih so nekatere lokalne skupnosti ohranile tradicionalno gojenje kavčukovca. V raziskavi sta bili primerjani nadzemna biomasa dreves (AGB) in porazdelitev ogljika v različnih debelinskih razredih dreves $(\mathrm{DBH}=$ premer drevesa na prsni višini) med sistemom Tembawang in konvencialno pridelavo kavčuka na plantažah v Zahodnem Kalimantanu, Indonezija. Analiza vegetacije je bila opravljena $\mathrm{v}$ dveh transektih tradicionalnega pridobivanja kavčuka imenovenega Tembawang in v konvencionalnih plantažah kavčukovca. Določitev nadzemne biomase je temeljila na alometričnih enačbah, zaloge ogljika so bile ocenjene iz odstotkov biomase. Celokupna nadzemna biomasa je bila v sistemu Tembawang večja kot $\mathrm{v}$ konvencionalnih plantažah kavčukovca in značilno različna $(p<0,01)$. Največja akumulacija nadzemne biomase je bila $\mathrm{v}$ obeh sistemih, Tembawangu in pri konvencionalni pridelavi kavčuka $\mathrm{v}$ debelinskih razredih nad $50 \mathrm{~cm}$. Nadzemna zaloga ogljika je bila v sistemu Tembawang 90,26 Mg C ha ${ }^{-1}$ in 42,01 Mg C ha-1 pri konvencionalni pridelavi. Največji delež shranjenega ogljika je bil v debelinskih razredih dreves nad $50 \mathrm{~cm}$, ocenjen na $62,58 \%$ pri Tembawangu in 49,24\% pri konvencionalni pridelavi kavčuka. Nadzemna biomasa in zaloga ogljika sta bili v tradicionalnem kmečkem gozdarstvu Zahodnega Kalimantana večji kot v različnih konvencionalnih sistemih, tudi ocenjene vrednosti so bile blizu tistim v drugotnih tropskih gozdovih. Tembawang sistem kmečkega gozdarstva ima dober potencial za shranjevanje ogljika in ohranjanja samoniklih sadnih dreves v Kalimantanu.

Ključne besede: shranjevanje ogljika; pleme Dayak; etnoekologija; plantaža; Tembawang

\footnotetext{
1 Tanjungpura University, Faculty of Mathematics and Natural Sciences, Department of Biology, Pontianak, West Kalimantan, Indonesia

2 Corresponding author, e-mail: rafdinal@fmipa.untan.ac.id

3 Tadulako University, Faculty of Mathematics and Natural Sciences,Department of Biology, Palu, Central Sulawesi, Indonesia

4 OSO University, Department of Marine Science, Pontianak, West Kalimantan, Indonesia

5 Muhammadiyah Sumatera Barat University, Faculty of Forestry, Department of Forestry, Padang, West Sumatra, Indonesia
} 


\section{INTRODUCTION}

Forest ecosystems are an important component of the terrestrial ecosystem. They contain more than half of biodiversity, and highly contribute to stored carbon. Trees are the main component in forest ecosystems containing about $677 \mathrm{Pg}$ or $80 \%$ of the total forest biomass (Kinderman et al., 2008). Forest ecosystems absorb carbon dioxide $\left(\mathrm{CO}_{2}\right)$ from the atmosphere through photosynthesis and increase in the average concentration of $\mathrm{CO}_{2}$ in the atmosphere can be reduced through carbon sequestration (C) (IPCC, 2007).

Carbon sequestration in forest ecosystems has become an important issue both in global climate change, climate discussions and in forest ecosystem studies. Forest conversion into other land-uses such as agriculture, settlement, and also forest degradation can pose a serious threat to sustaining carbon storage. Carbon storage in a forest ecosystem is mainly determined by growth factors, mortality, decomposition, disturbance, forest succession, and climate variations (Gough et al., 2008).

Indonesia has the third-largest area of tropical forest after Brazil and Congo, with an area of $92.133 \mathrm{M}$ ha (FAO, 2020). Furthermore, the potential for carbon stocks in natural forests in Indonesia is large, ranging from 7.5-264.70 t C ha-1 (Ministry of Forestry, 2010). In the period of 2000 to 2015 , the rate of deforestation of primary forests in Indonesia is also very high (FAO, 2015). Deforestation and forest degradation in Indonesia are generally caused by the settlement expansion driven by population growth, forest logging, and conversion to plantation / agricultural land (Prasetyo et al., 2011).

Kalimantan (Borneo) is the second-largest island in Indonesia, with a vast expanse of natural forests with high diversity and endemicity (Rhee et al., 2004). Among 109 tree families found in Kalimantan, Dipterocarpaceae family was dominated by the forest composition and more than half species in this group were endemic species in Kalimantan (Soepadmo and Wong, 1995). Deforestation in tropical forests in Kalimantan from 20002017 reached $6.04 \mathrm{M}$ ha, of which half was caused by land conversion to the plantation industry (Gaveau et al., 2017). According to Carlson et al. (2012), by 2020 the expansion of palm oil industries is projected to contribute about $0.12-0.15$ Gt $\mathrm{C}$ year-1 $\mathrm{CO}_{2}$ equivalent emissions.

Tembawang represents the term of agroforestry management practices by Dayak's tribe in Kalimantan. This term also represents the other management systems by local communities such as forests, plantations, rice fields, and settlements (Wahyuni, 2002). Tembawang and rubber agroforestry are part of the tropical rainforest in West Kalimantan. This area is a very important natural resource to provide oxygen and preserving carbon. Over the past few decades, the expansion of plantations, agriculture, and settlements in West Kalimantan has been a serious threat to Tembawang and rubber forests. Required anticipation of land-use changes to provide a better climate from assessing population and biomass in Tembawang and traditional rubber agroforestry for enhancing carbon storage. Preliminary research has been conducted in this traditional agroforestry, a total of 43 species and 8 dominant species were found (Rafdinal and Pitopang, 2019). This study aims to compare the standing biomass of Tembawang and conventional rubber agroforestry related to carbon storage and mitigation of climate change.

\section{MATERIALS AND METHODS}

\subsection{DESCRIPTION OF RESEARCH AREA}

This study was located at Kayu Lapis Road, Kilometer 21, Nanga Pemubuh Village, Sekadau Hulu District, Sekadau Regency, West Kalimantan Province, Indonesia (Figure 1). Sekadau Hulu is one of 7 districts in Sekadau Regency, has an area of $\pm 869.7 \mathrm{~km}^{2}$. Sekadau Hulu District is geographically located in the southern part of Sekadau Regency, consists of 15 villages including Nanga Pemubuh. Nanga Pemubuh village has an area of $89.92 \mathrm{~km}^{2}$ and is located $55 \mathrm{~km}$ from the central district. In general, this region's has relatively high annual rainfall and wet tropical climate. Based on the record of Meteorological, Climatological, and Geophysical Agency of Indonesia (Indonesian Statistics, 2016), the highest rainfall in 2011 occurred in November $(826 \mathrm{~mm})$ and the lowest in May $(118 \mathrm{~mm})$. The average monthly temperature ranged from $24.8-27.3^{\circ} \mathrm{C}$, and there was no dry season. Soil conditions are generally very heterogeneous, with the $\mathrm{pH}$ of soil $\mathrm{H}_{2} \mathrm{O}$ in horizon-A ranging from 3.69 to 5.55.

\subsection{FOREST INVENTORY}

Analysis of vegetation in each sampling site was carried out by a belt transect method. The transects were further divided into $20 \mathrm{~m} \times 20 \mathrm{~m}$ plots. In each plot, all individuals with $\geq 10 \mathrm{~cm} \mathrm{DBH}$ (Diameter at Breast Height) were tagged, measured, and identified. The girth and height of each individual were measured. The plant specimens were identified. Frequency, density, basal area, and Importance Value Index (IVI) were calculated following Misra (1968), Mueller-Dombois and Ellenberg (1974). Trees were grouped into five DBH classes i.e. 10$20 \mathrm{~cm}, 20-30 \mathrm{~cm}, 30-40 \mathrm{~cm}, 40-50 \mathrm{~cm}$, and $>50 \mathrm{~cm}$ and the density and Aboveground biomass (AGB) distribution under each $\mathrm{DBH}$ class were analyzed. 


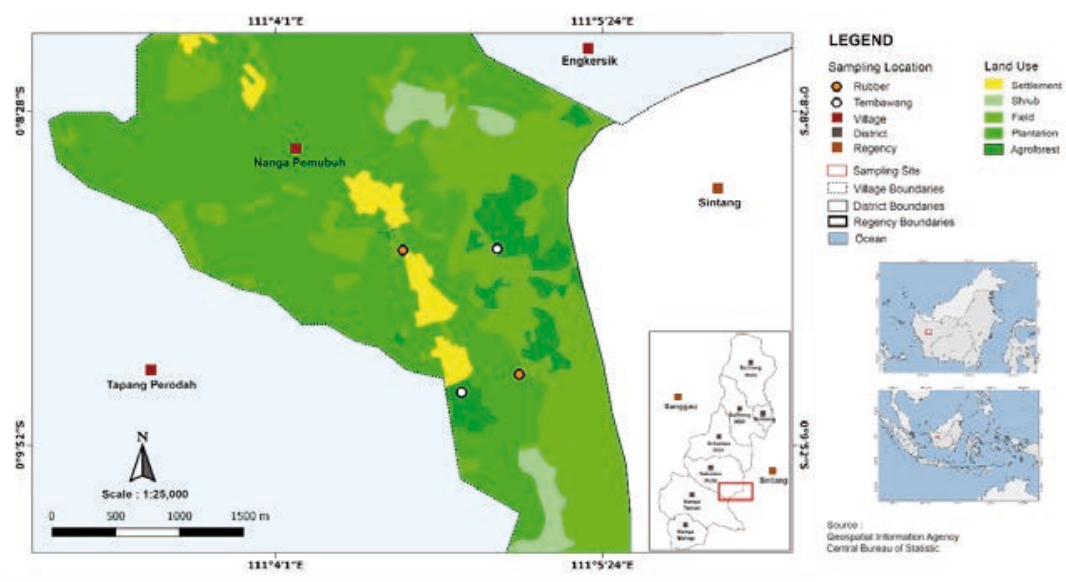

Figure 1: Location and land use of the study site

\subsection{ESTIMATION OF ABOVEGROUND BIOMASS}

The AGB in different tree diameter classes in each site was estimated using the following mentioned model (Ketterings et al., 2001):

$$
A G B=0.11 \rho D^{2.62}
$$

Where:

$\rho=$ wood density

$\mathrm{D}=$ diameter at breast height

The aboveground biomass for all diameter classes was summed to calculate the total aboveground biomass in each agroforestry type. The values for the Tembawang and the traditional rubber were compared using t-test analysis.

\subsection{ESTIMATION OF CARBON}

The aboveground biomass carbon storage was calculated by assuming that the carbon content is $50 \%$ of the total aboveground biomass (Brown, 1997; Cannel and Dewar, 1995; Dixon et al., 1994; Ravindranath et al., 1997; Richter et al., 1995; Schroeder, 1992).

\section{RESULTS AND DISCUSSION}

\subsection{STAND CHARACTERISTICS}

Twenty-eight species were recorded from the Tembawang agroforestry, and 31 species were recorded from the conventioal rubber plantation. The density of woody species ( $\geq 10 \mathrm{~cm}$ DBH) was greater in Tembawang (195 trees ha ${ }^{-1}$ ) than in traditional rubber agroforestry (190 trees ha-1), but not statistically different $(p>0.5)$. Based on density, Hevea brasiliensis Müll. Arg. (57.50 trees $\mathrm{ha}^{-1}$ ) and Durio zibethinus L. (26.25 trees $\mathrm{ha}^{-1}$ ) were the dominant species in the Tembawang agroforestry and these two species accounted for $31 \%$ of $\mathrm{ha}^{-1}$ ) and Durio zibethinus (18.33 trees $\mathrm{ha}^{-1}$ ) were the dominant and codominant species, respectively. The basal area was greater in the Tembawang agroforestry $\left(1,560.97 \mathrm{~m}^{2} \mathrm{ha}^{-1}\right)$ than in the conventional rubber plantation $\left(811.27 \mathrm{~m}^{2} \mathrm{ha}^{-1}\right)$ (Table $1)$.

Tembawang and traditional rubber agroforestry in Dayak Tribe were implemented for decades. Both Tembawang and conventionalrubber agroforestry were managed traditionally from generation to generation. The differences in these systems is based on the constituent trees species of each agroforestry type (Rafdinal and Pitopang, 2019). Tembawang is former forest land that is used for planting fruit trees for providing food or traditional ceremonies need by local people, therefore the 3 main constituent species are Durio zibethinus, Nephelium lappaceum, and Artocarpus sp. However, in the recent decades, Tembawang agroforestry has began to be planted rubber trees by local people, and the latex is sold to industries or companies in the city, therefor now the rubber trees dominated Tembawang agroforestry.

Rubber plantation was generally formed from land clearing by local communities in the decade 2000-2010 in West Kalimantan to support the national rubber industry, rubber latex had high selling value at that time (Indonesia-Investment, 2018). However, some conventional rubber plantations still preserved trees used for daily needs such as wood and fruit trees. Thus, Durio zibethinus and Shorea species still exist besides the dominant rubber trees. 
Table 1: Stand characteristics of Tembawang and conventional rubber agroforestry of West Kalimantan

\begin{tabular}{lll}
\hline & Agroforestry & Conventional Rubber \\
\cline { 2 - 3 } Variables & Tembawang & 31 \\
\hline Species richness (number of species) & 28 & 190 \\
Stand density (trees ha' ${ }^{-1}$ & 195 & 18.33 \\
Density of dominant tree species: & & 38.33 \\
Durio zibethinus L. & 26.25 & 10.00 \\
Hevea brasiliensis Müll. Arg. & 57.50 & 10.00 \\
Nephelium lappaceum L. & 11.25 & 10.00 \\
Artocarpus sp. & 13.75 & - \\
Shorea stenoptera Burck. & 12.50 & 10.00 \\
Artocarpus integer Merr. & 10.00 & 13.33 \\
Anacardium occidentale L. & - & 10.33 \\
Shorea leprosula Miq. & - & 811.27 \\
Shorea macrophylla (de Vr.) Ashton & - & $1,560.97$ \\
Basal area (m² ha ${ }^{-1}$ ) & &
\end{tabular}

\subsection{ABOVEGROUND BIOMASS DISTRIBUTION}

Although the young individuals belonging to $10-$ $20 \mathrm{~cm}$ DBH class dominated both forests for tree density (Figure 2), the AGB accumulation was greater in the up $50 \mathrm{~cm}$ diameter class in Tembawang agroforestry forest and traditional rubber plantation (Figure 3). The contribution of AGB by higher diameter classes generally increases in both agroforestry. The contribution of $>50 \mathrm{~cm}$ diameter trees to AGB is greater in Tembawang agroforestry $(62.58 \%)$ than in traditional rubber plantations (49.24\%).

Rubber growth is faster than in other trees in these agroforestry systems, latex harvesting of rubber trees was carried out when entering 5-6 years vegetation ages with $45 \mathrm{~cm}$ girth or about $15 \mathrm{~cm}$ trunk diameter for 25 30 years production period (Damanik et al., 2010). After production age, rubber trees were usually felled and replanted, so that the highest density of rubber agroforestry was dominantly distributed in the lower diameter class, whereas tree density in Tembawang agroforestry was mainly distributed in the higher diameter class, covered by old fruit trees that have been down through generations. Further, the difference in density distribution from diameter class caused the basal area and overall AGB value of Tembawang were greater than rubber plantations.

\subsection{TOTAL ABOVEGROUND BIOMASS AND CARBON STORAGE}

The total AGB of Tembawang agroforestry (180.51
$\left.\mathrm{Mg} \mathrm{ha}^{-1}\right)$ was significantly greater $(p<0.01)$ than traditional rubber plantation $\left(85.01 \mathrm{Mg} \mathrm{ha}^{-1}\right)$. A primary forest can store AGB of up to $\pm 350 \mathrm{Mg} \mathrm{ha}^{-1}$ while a secondary forest varies considerably between $59-140 \mathrm{Mg} \mathrm{ha}^{-1}$ (Stas, 2014). The value of AGB in a forest ecosystem depends on the composition and structure of the forest. The AGB value of rubber agroforestry was in the range of secondary forest values and was still in the intensive tree crop plantation value range of $60-120 \mathrm{Mg} \mathrm{ha}^{-1}$ (Hairiyah et al., 2011). The ABG value of Tembawang agroforestry was higher than the average AGB value of the secondary forest. The composition and structure of Tembawang agroforestry were quite varied and the conditions had been preserved for generations so that it had large AGB potential, but not as large as primary forest.

The aboveground carbon stored by Tembawang and traditional rubber forests was 90.26 and $42.01 \mathrm{Mg}$ $\mathrm{C} \mathrm{ha}^{-1}$, respectively and were significantly different $(p<$ $0.01)$. Carbon organic was mostly stored in up $50 \mathrm{~cm}$ DBH class in Tembawang (62.58 \%) and traditional rubber $(49.24 \%)$. The younger (10-20 cm DBH class) trees, which had the highest density in both forests, stored only $3.52 \%$ of total carbon in the Tembawang agroforestry and $5.52 \%$ of traditional rubber (Table 2).

Aboveground carbon storage of Tembawang agroforestry was two times higher than rubber plantations, in terms of carbon storage Tembawang agroforestry was better, but the age of the community and vegetation cycle also to be considered. When compared to other agroforestry systems, the Tembawang agroforestry system stored more carbon. In a comprehensive report 


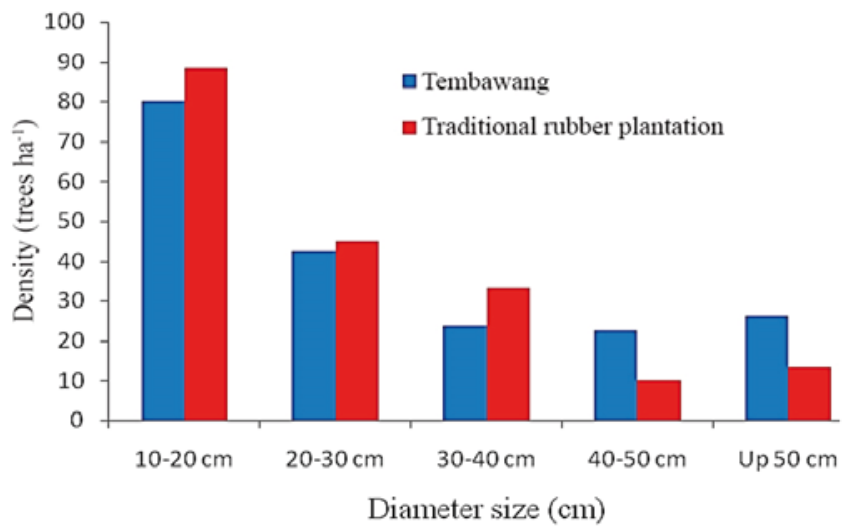

Figure 2: Tree density in different diameter classes in Tembawang forest and traditional rubber of West Kalimantan

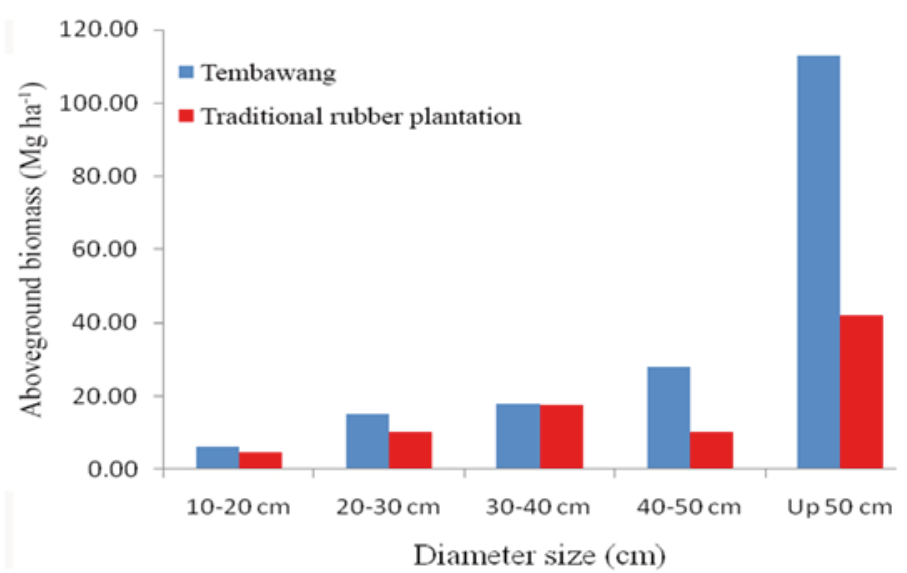

Figure 3: Aboveground biomass at different diameter classes from Tembawang forest and traditional rubber of West Kalimantan

Table 2: Carbon storage in different tree diameter classes in Tembawang forest and conventional rubber of West Kalimantan

\begin{tabular}{lllll}
\hline & \multicolumn{2}{l}{ Tembawang Forest } & \multicolumn{2}{l}{ Conventional Rubber Forest } \\
\cline { 2 - 5 } $\begin{array}{l}\text { Diameter Size } \\
(\mathrm{cm})\end{array}$ & $\begin{array}{l}\text { Density } \\
(\%)\end{array}$ & $\begin{array}{l}\text { Carbon Storage } \\
(\%)\end{array}$ & $\begin{array}{l}\text { Density } \\
(\%)\end{array}$ & $\begin{array}{l}\text { Carbon Storage } \\
(\%)\end{array}$ \\
\hline $10-20$ & 41.03 & 3.52 & 44.49 & 5.52 \\
$20-30$ & 21.79 & 8.39 & 23.68 & 12.19 \\
$30-40$ & 12.18 & 10.02 & 17.54 & 20.94 \\
$40-50$ & 11.54 & 15.49 & 5.26 & 12.07 \\
$>50$ & 13.46 & 62.58 & 7.02 & 49.24 \\
\hline
\end{tabular}

from Schroeder (1984), agroforestry systems in humid areas had an average value of $50 \mathrm{Mg} \mathrm{C} \mathrm{ha}^{-1}$, whereas in another report, Takimoto et al. (2008) reported the value of biomass $\mathrm{C}$ storage ranged from 0.7 to $54.0 \mathrm{Mg}$ $\mathrm{C} \mathrm{ha}^{-1}$ in traditional and improved agroforestry in West Africa. Compared to the dominating palm oil and agarwood industries in Indonesia and Malaysia, with car- bon storage values of 14.35 to $37.88 \mathrm{Mg} \mathrm{C} \mathrm{ha}^{-1}$ (Awang Besar et al., 2020), the carbon storage value of rubber plantation had higher value. In the same DBH range $(\geq$ $10 \mathrm{~cm}$ ), the carbon storage value in Tembawang agroforestry was in the aboveground carbon storage range of secondary tropical forests in Maluku, Indonesia with an average value of $70.3 \mathrm{Mg} \mathrm{C} \mathrm{ha}^{-1}$ (Stas, 2014). 


\section{CONCLUSIONS}

The aboveground carbon storage value of the traditional Tembawang and Rubber agroforestry system was estimated at 90.26 and $42.01 \mathrm{Mg} \mathrm{C} \mathrm{ha}^{-1}$. The traditional agroforestry system of the Dayak tribe community of Sekadau Regency, West Kalimantan had better impact and potential to preserve carbon than an intensive agroforestry system. The preservation of several species of fruit trees in the agroforestry system was major contribution to carbon storage.

Tembawang agroforestry has high potential for carbon storage compared to rubber plantations and varied different agroforestries, also the value was almost similar to carbon storage potential in secondary tropical forests. Local people's knowledge in traditional agroforestry systems need to be reported. The system could become a model in developing productive agroforestry and minimizing carbon emission.

\section{ACKNOWLEDGEMENTS}

The research was funded by the Directorate of Research and Community Service Research and Development Directorate-General for Research and Development of the Ministry of Research, Technology, and Higher Education in accordance with the Research Contract No. 107 / SP2H / LT / DRPM / IV / 2017 dated April 3 , 2017. The authors wish to thanks to the Directorate of Research and Community Service of the Directorate General of Research and Technology Research and Development of Higher Research, Technology, and Higher Education.

\section{REFERENCES}

Awang Besar, N., Suardi, H., Phua, M., James, D., Mokhtar, M., Ahmed, M.F. (2020). Carbon Stock and Sequestration Potential of an Agroforestry System in Sabah, Malaysia. Forests, 11, 1-16. https://doi.org/10.3390/f11020210

Brown, S. (1997). Estimating Biomass and Biomass Change of Tropical Forests. Rome: FAO Forestry.

Cannell, M.G.R., Dewar, R.C. (1995). The Carbon Sink Provided by Plantation Forests and Their Products in Britain. Forestry, 68, 35-48. https://doi.org/10.1093/forestry/68.1.35

Carlson, K.M., Curran, L. M., Asner, G. P., Pittman, A. M., Trigg, S. N., Adeney, J. M. (2012). Carbon emissions from forest conversion by Kalimantan oil palm plantations. Nature Climate Change, 1-5. https://doi.org/10.1038/nclimate 1702

Damanik, S., Syakir M., Tasma, M., Siswanto. (2010). [Cultivation and Post-harvesting of Rubber]. Bogor: Pusat Penelitian dan Pengembangan Perkebunan. [In Indonesian].
Dixon, R. K., Solomon, A. M., Brown, S., Houghton, R. A., Trexier, M. C., Wisniewski, J. (1994). Carbon pools and flux of global forest ecosystems. Science, 263, 185-190. https:// doi.org/10.1126/science.263.5144.185

[FAO] Food and Agriculture Organization. (2010). Global Forest Resource Assessment paper 2010: Main Report. FAO forestry 163340.

[FAO] Food and Agriculture Organization. (2015). Global Forest Resources FAO, Assessment 2015: Country Report Indonesia. Rome.

[FAO] Food and Agriculture Organization. (2020). Global Forest Resources FAO, Assessment 2020: Main Report. Rome.

Gaveau, D. L. A., Locatelli, B., Salim, M.A., Yaen, H., Pacheco, P., Sheil, D. (2017). Rise and fall of forest loss and industrial plantations in Borneo (2000-2017). Conservation Letters, 1-8. https://doi.org/10.1111/conl.12622

Gough, C. M., Vogel, C.S., Schmid, H. P., Curtis, P.S. (2008). Control on annual Forest Carbon Storoge: Lessons from the Past and Prediction for the Future. BioScience, 58, 609-622. https://doi.org/10.1641/B580708

Hairiah, K., Dewi, S., Agus, F., Velarde, S., Ekadinata, A., Rahayu, S., van Noordwijk, M. (2011). Measuring Carbon Stocks Across Land Use Systems: A Manual. Bogor, Indonesia. World Agroforestry Centre (ICRAF). SEA Regional Office, 154 pages.

[IPCC] Intergovernmental Panel on Climate Change. (2007). Summary for policymakers. In: Solomon, S.Q.D., Manning, M., Chen, Z., Marquis, M., Averyt, K.B., Tigmor, M., Miller, H.I. (eds) Climate Change 2007: The physical science basis. Contribution of working group I to the fourth assessment report of intergovernmental panel on climate change. London: Cambridge University Press.

Indonesia-investment. (2018). Karet: Indonesia Investments. Available from: www.indonesia-investments.com. Accessed 25 April 2019.

Indonesian Statistics West Kalimantan Province. (2016). [Amount of Rainfall and Rainy Days at Meteorological, Climatological, and Geophysical Agency: BMKG Observation Station from 2000-2015]. Available from: http://kalbar.bps. go.id/. Accessed 7 November 2016. [In Indonesian].

Ketterings, Q. M., Coe, R., van Noordwijk, M., Ambagau, Y., Palm, C. A. (2001). Reducing uncertainty in the use of allometric biomass equations for predicting aboveground tree biomass in mixed secondary forests. Forest Ecology and Management, 146, 199-209. https://doi.org/10.1016/S03781127(00)00460-6

Kindermann, G. E, McCallum, I., Fritz, S., Obersteiner, M. (2008). A Global Forest Growing Stock, Biomass and Carbon Map based on FAO Statistics. Silva Fennica, 42, 387396. https://doi.org/10.14214/sf.244

Ministry of Forestry of Indonesia. (2010). [Carbon Stocks on Various Type of Forest and Vegetation in Indonesia]. Bogor: Badan Litbang Kehutanan. [In Indonesian].

Misra, R. (1968). Ecology WorkBook. Calcutta: Oxford and IBH Publishing Company.

Mueller-Dombois, D., Ellenberg H. (1974). Aims and Methods of Vegetation Ecology. New York: John Wiley and Sons.

Prasetyo, L. B., Wijaya, C. I., Setiawan, Y. (2011). Spatial model approach deforestation: for Case study in Java Island, In- 
donesia. In: Y. Trisurat, R. P. Shresthaand R. Alkemadeeds. LandUse, Climate Change and Biodiversity Modeling: Perspectives and Applications. Hershey: IGI Global.

Rafdinal, Pitopang, R. (2019). The phytososiological of agroforestry Tembawang at secundary forest Sekadau Hulu in West Kalimantan Indonesia. IOP Conf. Series: Journal of Physics: Conf. Series, 1242, 1-7. https://doi.org/10.1088/17426596/1242/1/012041

Ravindranath, N. H., Somashekhar, B. S., Gadgil, M. (1997). Carbon flow in India forests. Climatic Change, 35, 297-320. https://doi.org/10.1023/A:1005303405404

Rhee, S., Kitchener, D., Brown, T., Merrill, R., Dilts, R., Tighe, S. (2004). Report on Biodiversity and Tropical Forests in Indonesia. Submitted in accordance with Foreign Assistance Act Sections 118/119. USAID/Indonesia, Jakarta.

Richter, D. D., Markewitz, D., Dunsomb, J. K., Wells, C. G., Stuanes, A., Allen, H. L., Ureego, B., Harrison, K., Bonani, G. (1995). Carbon cycling in a loblobby pine forest: Implication for the missing carbon sink and for the concept of soil. pp. 223-251. In: W.W. McFee \& J.L. Kelly (eds.) Carbon Forms and Function in Forest Soils. Soil Science Society of America, Madison.

Schroeder, P. (1984). Carbon storage benefits of agroforest- ry systems. Agroforestry Systems, 27, 89-97. https://doi. org/10.1007/BF00704837

Schroeder, P. (1992). Carbon storage potential of short rotation tropical tree plantations. Forest Ecology and Management, 50, 31-41. https://doi.org/10.1016/0378-1127(92)90312-W

Soepadmo, E., Wong, K. M. (1995). Tree Flora of Sabah and Sarawak: Volume One. Forest Research Institute (FRIM), Sabah Forestry Department and Sarawak Forestry Department, Kuala Lumpur, Malaysia.

Stas, S. M. (2014). Above-ground biomass and carbon stocks in a secondary forest in comparison with adjacent primary forest on limestone in Seram, the Moluccas, Indonesia. Working Paper, 145, Bogor, CIFOR. https://doi. org/10.17528/cifor/005258

Takimoto, A., Nair, P. K. R., Nair, V. D. (2008). Carbon stock andsequestration potential of traditional and improved agro-forestry systems in the West African Sahel. Agriculture, Ecosystems \& Environ, 125, 159-166. https://doi. org/10.1016/j.agee.2007.12.010

Wahyuni, T. (2002). Development model of community forestry. Research Report. Forest Research Institute, Samarinda. Available from: http://fao.org/3/ad511e0d.htm\#bm13/. Accessed 11 November 2016. 